\title{
ETHICS AND BUSINESS ETHICS, AND THE FINANCIAL CRISIS. ABOUT AXIOLOGY AND BUSINESS: HISTORY OF SLAVERY IS LIKE A CIRCLE
}

\author{
Dawid "Renas" \\ Bunikowski ${ }^{1}$
}

\begin{abstract}
The papers acquaints the readers with problems of ethics and business ethics in context of the financial crisis. The article is to underline a role of ethics in business. An ethical approach is incredibly important in the economy and the business activity. There is no good economy and market without axiology in social order. There is no economy and economic activities without much deeper foundations based on moral universal values such as honesty or transparency or dignity. We should go back to papal teaching and classics of moral philosophy. I believe that we can create the real axiology including such the values. The global financial crisis is rather an axiological crisis than strictly economic because the foundations and real reasons of the financial crisis have strictly moral character. Greed, profit, fraud, misinformation, new morality of homo economicus created the new world of consumers and the structurally and institutionally hermetic world of the markets and the corporations. It is a sad but more realistic view of the corporations and economy. History of slavery is like a circle: free people became stupid consumers; free people working in corporations became its cynical or ordinary slaves, the honest became the dishonest; free people became dishonest businessmen and businesswomen, without heart, mercy and reason. The system we live is rotten (politics, law, business, media, consumerism ideology), requiring changes. We should start with moral education to make ordinary people, the citizens, who create the commonwealth, really more responsible, competent and free in choices.
\end{abstract}

Keywords: morality, ethics, business ethics, axiology, values, financial crisis, slavery, freedom, moral philosophy, law, social order, consumerism, rotten system

INTRODUCTION. MY AIM.

\footnotetext{
${ }^{1}$ He is a Postdoctoral Researcher at the University of Eastern Finland, in Law School in Joensuu (2013-2015). He is also a Distinguished Academic Associate in the Centre for Law and Religion, Cardiff Law School, at Cardiff University (since 2013).

E-mail: dawid.bunikowski@uef.fi
} 
If one man is colonizing another man, is not a slavery? We must follow a long way of thinking to consider this statement more seriously in the contemporary time. Let us start our talk about the world where ethics, also in business, appears. Let us start our way through the current world. The economic and financial crisis which begun in 2007 (in the U.S. in a mortgage market) and was wide-spreading in 2008 and 2009 around the whole world is still visible in both the world economy and the concrete economies. I do not want to propose an economic analysis to answer the question what was the reason of the crisis. I propose an axiological analysis, a story about values, or rather about a lack of values in economy, market, business. That is my point of view.

The article is to underline a role of ethics in business, in business activity. An ethical approach is incredibly important in the economy and the business activity. There is no good economy and market without axiology in social order. There is no the good and well organized social order without the axiology of society: values, principles and rules understood as a common vision of evil and good, which are valid for all the people in the society, and which establish what is morally wrong and what is morally good, also in the market and in commercial relations between people, too.

First of all, I would like to write about Pope Benedict XVI and his opinion about ethics in the economy and business (it is the widest part of the article); the second, it directly concerns business ethics which is the next point of my considerations; the third, then - talking about the so called "business ethics" - the article relates to a definition of ethics in business and what the business ethics really is. It is also about practical problems with obeying some fundamental moral rules in business (I follow a businessman John Bogle's theory). The forth, it concerns so practical matters as corporate governance, viz. rules and principles of well-organized organizations, firms, financial institutions, with their respect for the moral/ethical values and the ethics; with respect for transparency in business activity; with realization of the truth and dignity values in institutional relations (i.e. a clear process of making decisions; a clear division of responsibilities and competencies; a clear and effective system of controlling board of directors), and with understanding the problem of social responsibility of business. I would like also to show you the case studies, in which the analysis of business ethics is more visible (see Bogle). I want to talk also about the catalogue of principles or values in business, with the philosophical background. 
The aim of my article is to describe the terms of business ethics, presenting also deeply axiological foundations of business and giving some examples of using the business ethics and corporate governance in practice, and underlying the role of business ethics in the market, business and economy. It should be clearly said that it is impossible to mention about the economy if the institutions of economy (services, organizations, rules) are not ethical and full of transparency. It will be difficult to fight with the reasons and effects of the global financial crisis without respect for the business ethics and the principles of corporate governance. That is the most important reason why I wrote this article. It is a very critical draft.

\section{WHAT IS THE WORLD WE LIVE IN?}

We live in the world full of highly modern and organized economy and societies. Leibniz would say that we live in the best world of the possible worlds. But the business world is still changing, not only in a morally good direction, about what I mention below. Capitalism, free market, appreciation of consumption are facts. Technique and technology in the market are still developing and new financial instruments, sophisticated services or different products are just created. Globalization of economy seems to be something completely obvious, too. Deregulation in some fields (e.g. financial markets) was often correlated with it. On the other hand, over-regulation in the law is visible (especially during the Crisis). The consumption reigns. We may want "new and new" services, products etc., often on credit. The market is full of innovations and new ideas how consumption may be developed. Firms are servants of our desire. They better know what you want and then you want what they want that you want. The technique is colonizing a man and human relations. Firms and people-consumers are still working much more hard. They are especially seeking benefits and much more money in the pockets or in the banking accounts. But these processes of the changes as globalization or development of the markets and the global economy include also - without positive effects such as an increase of wealth in the concrete countries and without negative affects such as the life consumption and the human relations and life mechanization - some additional dangers, i. e. an unfair activity in business, frauds, an collapse of trust and ethics and ethical norms in human, institutional and business relations etc. 
I think that a statement that the world of West is in a great moral crisis has no doubts. A disaster of traditional ethics in the $20^{\text {th }}$ century is a fact. People do not really know what they want, which values are important, where life goes. Nietzsche was in right: it is a collapse of traditional values and building of the new values by the re-valuation. A outstanding philosopher of law Aleksander Peczenik wrote me about it just in 2005 before his death. I maintain that the most fundamental reason of the global recent financial crisis (begun in 2007 in the U.S.) was the moral crisis. A greed which I mean as a "anti-value" was the reason of the economy crisis. The greed of people, organizations, institutions, governments... Even the father of capitalism and free market Adam Smith ${ }^{2}$ said that the economy must be based (and supported by) on religion, morality, humanity, not on another values. In my opinion, an ideology of consumption (what I call "consumptionism" or what is known as a consumerism) which treats a man as a consumer is a "king of life". I completely do not agree with this ideology and the business practice based on it. My article is against it. That is the reason that I consider the Catholic teaching so deeply and widely. That was a core of our life, including the business life, to the $18^{\text {th }}$ century when some values such as family, religion, trust, near human relations, hard work were collapsed and the greed and idea of easily reached wealth began the kings of life.

Even one lives in "the U.S. version of capitalism" and imagines that it is "the soul of capitalism", there is also the European version - "much gentler version", the version with "social obligations and restraints" . It must be said that some kind of real economy is an "economics of $\sin ^{\prime}$, as Samuel Cameron wrote in 2002. It concerns economy based on greed and envy (jealousy).

\footnotetext{
${ }^{2}$ About Adam Smith's theory concerning deep relations of the economy with religion: J. Evensky, Adam Smith's Moral Philosophy. A Historical and Contemporary Perspective on Markets, Law, Ethics, and Culture, Cambridge 2005. Jerry Evensky, analyzing Smith's ideas, wrote: "Smith reading of history convinced him that if religious institutions and positive law evolve in constructive ways they complement the natural progress of opulence and when these three dimensions are evolving constructively together, humankind will be moving toward the human prospect" (p. 108; underlining - mine). It is so because Smith, especially the mature, saw economy and all human life as based on religion and faith: "For the mature Smith, the deity is not about institutional doctrine or scientific proof, the deity is about faith. (...) The faith is the source of Smith's hope for humankind and the motivation for his life as a moral philosopher, a life committed to representing the invisible connecting principles that can lead humankind toward that benevolent prospect with which the deity has endowed humankind: <the liberal plan of equality, liberty and justice>” (p.108).

${ }^{3}$ See: W. Greider, The Soul of Capitalism, New York, London, Toronto, Sydney, Singapore 2003, p. 33.

${ }^{4}$ S. Cameron, The Economics of Sin. Rational Choice or No Choice at All?, Cheltenham, UK; Northampton, USA 2002.
} 


\section{ABOUT ETHICS, MORALITY, AND FINANCIAL CRISES.}

Let me say few words about morality, ethics and financial crises to make it clear what I mean using these terms. Of course, first of all, we must say that we could talk about many concepts of ethics or morality. Morality means a group of norms which regulate what is wrong and what is good. Morality is about norms of human behavior and on the other hand, it is about human behavior itself, treated as social facts. It concerns human activity but also the mind. There are different kinds of morality: public and private, elementary and perfectionist, religious and secular. The ethics is always a systemized lecture on a vision of evil and good. The ethics includes more deeply axiological justification of the norms. There are many kinds of the ethics: the Catholic ethics, the Muslim ethics, the Buddhist ethics, the humanistic ethics etc. In this article we can use these terms (morality, ethics) changeably, as I also do with such the concepts as market, economy, business. The Catholic ethics plays the very fundamental role in the world, in my opinion, but not only - many researchers in ethics agree that a voice of the Church seems to be stable in moral/ethical cases and requires highly standards in human life. It concerns the economy, the market, too. Knowing some differences between the following concepts: a market and an economy, I use them changeably, as I said above. It is in order not to complicate my considerations in this short article.

And the last but not least, axiology means a theory of values, and axiology is about values. It is about what is important of the important states of things (e.g. justice, equality, family, freedom, money, love and so on). We may say about axiology of the law, but we may also talk about axiology in business: on one hand, the institutional axiology which is written in the official documents, and on the other hand, the real axiology which based on carrying out the case studies and seeking values in our concrete behavior or activity, not in pompous acts or documents. That is the great difference, not only from methodological point of view. I mean the institutional axiology is often full of hypocrisy and it is better to analyze the real axiology, the real morality of people in business to know what rules are acceptable or not; what is really wrong or not. Of course, it is not contrary to my proposal of classification of values in business ethics, made in order to highlight them or systemize it (one of the next chapters, viz. point 8). 
Some relations between morality, law and economics must be explained now. There are many social sub-systems in social system. Law, morality, economy, army, culture, education, religion etc. are some normative or strictly non-normative sub-systems.

As we would say at this place without any confusion, morality is an open term there are many kinds of morality (public, private, elementary, perfectionist, Catholic, Muslim etc.). There are also universal moral values (do not kill, do not steal, be honest etc.). Analyzing relations between law, economy and morality, we must add that these are so called autopoieitic systems (like morality, law, economy, army, culture; e.g. they are selfregulated and have the so called „a rule of recognition”). Connections between law and morality are obvious and widespread (on three levels: making law, law application, interpretation of law). Economy is regulated in some fields and spheres by the law of state. Law is based on public and elementary morality (but not only - in Quatar and the Saudi Arabia also on religion). The conclusion is that economy is related with morality. For example, 1) article 471 of the Polish civil code, which relates to the honesty value, 2) Polish Judicial Registration Act of 1997 - concerns the transparency value, 3) paying as an human act, without enforcement, e. g. for company, assets, shares, commodities, goods, products or services is absolutely moral - but fraud is deeply morally wrong act (I omit a problem of price, of course).

The global economy and the justice value were the subject of Pope Benedict XVI's teaching in the latest years. The Pope rightly wrote in a famous encyclical "Caritas in veritate" that "...justice must be applied to every phase of economic activity (underlined text - mine), because this is always concerned with man and his needs. Locating resources, financing, production, consumption and all the other phases in the economic cycle inevitably have moral implications. Thus every economic decision has a moral consequence" . Of course, we can ask him which theory of justice to use in economy by the law: the egalitarian theory, Rawls' theory, Hayek and Nozick's theory, The Church's? In the time of not only the global economy but also the financial crisis begun in 2007 in the U.S. we could consider the relations between morality and financial crises, asking noisily: is capitalism a phenomenon as a source of moral evil, greed and decay? Is the state protection and bail-out an activity as an immoral support, and the regulatory reforms as a socialist nightmare and bureaucratic over-regulation? These are rhetoric questions, it seems.

\footnotetext{
${ }^{5}$ Benedict XVI, Caritas in veritate, Vatican 2009, 37. Generally, all underlined parts of the text (words, statements) are mine.
} 
It should be said that the history of financial crises is very long and we have had many types of financial crises: banking crises, speculative bubbles and crashes, international financial crises and wider economic crises, and we have many theories which interpret them (e.g. Marxists, Hayek, Keynes, Minsky, coordination games, herding models and learning models, Sornette etc.). We could also consider many economic reasons of the crisis such as: growth of the housing bubble, easy credits conditions and liberal credit policy in banks, sub-prime lending, predatory lending, deregulation in the law, increased debt burden and over-leveraging, financial innovation and complexity (e.g. using derivatives), boom and collapse of the shadow banking system, commodity bubble, systematic crisis. Many causes have been proposed, with varying weight assigned by experts. But we do not want to see one fundamental reason of the crash in the commercial relations and of the collapse of the market what we call "the financial crisis", the greatest since the time of the Great Depression of 1929-1932. It is a reason full of axiological and moral connection. That is a greed. It is negative value in the field of morality. I would say that it is the "anti-value". The greed dominated the market in the recent years.

\section{ETHICS IN THE GLOBAL ECONOMY IN THE FORMER POPE BENEDICT XVI'S TEACHING.}

It is necessary to present deeper moral or axiological foundations of the economy before we are talking about the business ethics and the principles of corporate governance. I join these two ideas in such the way: ethics in business, the business ethics, moral values in business, whatever we call them, are a basis or core of corporate governance; morality and moral values are or should be the core of structure, functioning, processes, legal order and organizational culture of corporations. Thus I would like to use especially some aspects of the former Pope Benedict XVI's teaching (who resigned and left the Holy See on the $28^{\text {th }}$ of February in 2013 but also left the great teaching about ethics in the market, economy and business; the teaching of so important significance).

Benedict XVI says not only that the greed is the most important reason of the financial crisis. He generally accepts the principles of capitalism. According to his teaching,

1. Property itself is not an evil;

2. Capitalism is not a result of evil;

3. But using property may be morally bad; 
4. And some economic behaviors seems to be really morally wrong;

5. Moral values must be visible in economy and economic relations;

6. Honesty, truth and justice as moral values should be conceptualisated in legal regulations and legal order.

But the most important idea of his teaching is that law and economy must not exist without morality.

In many places of the papal document Benedict XVI returns to the idea of not only commercial logic in the economy and in the market: "Economic activity cannot solve all social problems through the simple application of commercial logic (underlined - D.B.). This needs to be directed towards the pursuit of the common good, for which the political community in particular must also take responsibility. Therefore, it must be borne in mind that grave imbalances are produced when economic action, conceived merely as an engine for wealth creation, is detached from political action, conceived as a means for pursuing

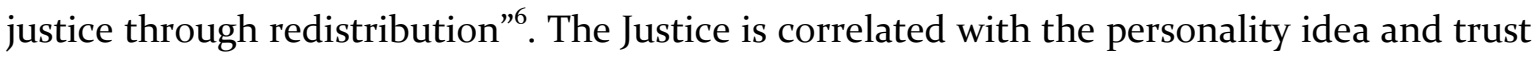
as a basis of human relations. He teaches: "In a climate of mutual trust, the market is the economic institution that permits encounter between persons, inasmuch as they are economic subjects who make use of contracts to regulate their relations as they exchange goods and services of equivalent value between them, in order to satisfy their needs and desires. The market is subject to the principles of so-called commutative justice, which regulates the relations of giving and receiving between parties to a transaction. But the social doctrine of the Church has unceasingly highlighted the importance of distributive justice and social justice for the market economy, not only because it belongs within a broader social and political context, but also because of the wider network of relations within which it operates" ${ }^{\prime}$. In Benedict XVI's opinion, the economy area is not morally neutral - it must not be so: "The Church's social doctrine holds that authentically human social relationships of friendship, solidarity and reciprocity can also be conducted within economic activity, and not only outside it or "after" it. The economic sphere is neither ethically neutral, nor inherently inhuman and opposed to society. It is part and parcel of human activity and precisely because it is human, it must be structured and governed in an ethical manner" . And in the another place he adds: "The great challenge before us,

\footnotetext{
${ }^{6}$ Ibidem, 36.

${ }^{7}$ Ibidem, 35 .

${ }^{8}$ Ibidem, 36.
} 
accentuated by the problems of development in this global era and made even more urgent by the economic and financial crisis, is to demonstrate, in thinking and behaviour, not only that traditional principles of social ethics like transparency, honesty and responsibility cannot be ignored or attenuated, but also that in commercial relationships the principle of gratuitousness and the logic of gift as an expression of fraternity can and must find their place within normal economic activity. This is a human demand at the present time, but it is also demanded by economic logic. It is a demand both of charity and of truth" ${ }^{9}$. Even a term "logic" is a little exaggerated it seems to be a correct world to find a conscience, moral intuitions and values in the market and business.

According to the Pope Benedict the problem is that economic or financial instruments can be badly used. He does not talk that the capitalism system is only morally bad but he teaches: "The Church has always held that economic action is not to be regarded as something opposed to society. In and of itself, the market is not, and must not become, the place where the strong subdue the weak. Society does not have to protect itself from the market, as if the development of the latter were ipso facto to entail the death of authentically human relations. Admittedly, the market can be a negative force, not because it is so by nature, but because a certain ideology can make it so. It must be remembered that the market does not exist in the pure state. It is shaped by the cultural configurations which define it and give it direction. Economy and finance, as instruments, can be used badly when those at the helm are motivated by purely selfish ends. Instruments that are good in themselves can thereby be transformed into harmful ones. But it is man's darkened reason that produces these consequences, not the instrument per se. Therefore it is not the instrument that must be called to account, but individuals, their moral conscience and their personal and social responsibility"

The dark side of human nature implies that sometimes we are morally wrong in business. We are full of greed, envy, ambitions, fame and pleasure, desires, thinking of money, fear (because of our career future and social recognition), or lie; thus our speech is not about fraternity, it is about money and new goods we want to eat, see, have or have, see, eat. We want to eat a cake and have a cake, i.e. many cakes, still the new ones. It is an existential drama how free or relatively free people who are proud workers become ordinary and clear slaves in corporations, breaking own conscience in doing things totally morally

\footnotetext{
${ }^{9}$ Ibidem.

${ }^{10}$ Ibidem.
} 
wrong, not only morally doubtful (because the fact that they do the second category of bad things is obvious now after the lesson from the crisis). And how stupid or at least a little silly consumers and clients we are, it is a narrative for the next story about King Bernard I Magnificent (Madoff) and many another kings of our life. Epictetus would teach us what freedom means: if we want too much from the world, having much desires, we are not free, we are just slaves of own desires. We do not follow our reason but our want. And it is easy to manipulate us in so many ways, using relevant psychologically tricky techniques or measures. Forget about Kant's moral imperative: people are to use people in own selfish interests or in corporation's interests (if an agnostic John Smith, who works in a corporation and appreciates it in, in fact, mystical or metaphysical euphoria "we are the best, we will win, the FIRM, WE have decided", thinks that its interests are his own interests and values it means the same, in a complete identifying). What is more socially harmful is that the another values are in an official sphere of corporations (codes of good practice, model of corporate governance, Corporate Social Responsibility and its implementation, ethical codes, public relations, ethical products and so on) and in unofficial sphere were we have real behavior, decisions, policies, and strategies of the management and their implementation by the slaves. It is a sad picture of maximization of profits, biological consumerism, slavery and misinformation history. I cannot be wrong in this description, it would be against facts, moral intuitions and experience.

What is interesting and fundamental Benedict proposes to consider a problem of ethics in business or in the economy market, analyzing four levels: consumers' level, corporations and people in corporations' level, and the state level, and the global level (international cooperation to supervise the market in the light of Justice and solidarity).

We live in the world of globalization: of markets, services, people, capital, products, cultures, even ideas. But Benedict does not say that globalization is morally wrong. Globalization, a priori, is neither good nor bad. According to the Pope, that is right that economy is changed in the globalization process: "In the global era, the economy is influenced by competitive models tied to cultures that differ greatly among themselves. The different forms of economic enterprise to which they give rise find their main point of encounter in commutative justice. Economic life undoubtedly requires contracts, in order to regulate relations of exchange between goods of equivalent value. But it also needs just laws and forms of redistribution governed by politics, and what is more, it needs works 
redolent of the spirit of gift. The economy in the global era seems to privilege the former logic, that of contractual exchange, but directly or indirectly it also demonstrates its need for the other two: political logic, and the logic of the unconditional gift" ${ }^{\prime \prime}$. But the globalization is not morally wrong: "The truth of globalization as a process and its fundamental ethical criterion are given by the unity of the human family and its development towards what is good. Hence a sustained commitment is needed so as to promote a person-based and community-oriented cultural process of world-wide integration that is open to transcendence. Despite some of its structural elements, which should neither be denied nor exaggerated, globalization, a priori, is neither good nor bad. It will be what people make of it"12.

The moral obligation of people is to correct malfunctions in the economy system to fight with poverty by the redistribution of wealth ${ }^{13}$ and to fight wit corruption ${ }^{14}$. Benedict absolutely knows that the role of state in the globalization and the welfare state idea are changing. He thinks of "pressing moral need for renewed solidarity, especially in relationships between developing countries and those that are highly industrialized"15. His thinking is "global" when he teaches about solidarity but it concerns also the concrete state and the poorer areas of these states where "some groups enjoy a sort of "superdevelopment" of a wasteful and consumerist kind which forms an unacceptable contrast with the ongoing situations of dehumanizing deprivation"16. That is the problem of Western Europe and the U.S. (the developing contrast between the poor and the rich). Benedict maintains that "Systems of social security can lose the capacity to carry out their task"17. He appeals for the creating the new economic model with the interesting role of the state as a partner in a social dialogue (that is the well-known for us idea of the so called third way between socialism and capitalism?): "Political authority also involves a wide range of values, which must not be overlooked in the process of constructing a new order of economic productivity, socially responsible and human in scale. As well as cultivating differentiated forms of business activity on the global plane, we must also promote a dispersed political

\footnotetext{
${ }^{11}$ Ibidem, 37.

${ }^{12}$ Ibidem, 42.

${ }^{13}$ Por. ibidem, 22, 42, 49. Also a liberal and democratic socialist Bertrand Russell supported this idea 50 years ago in The Impact of knowledge on the society, London, Sydney, Wellington 1952, p. 127.

${ }^{14}$ Por. Benedict XVI, 22.

${ }^{15}$ Ibidem, 49.

${ }^{16}$ Ibidem, 22.

${ }^{17}$ Ibidem, 25.
} 
authority, effective on different levels. The integrated economy of the present day does not make the role of States redundant, but rather it commits governments to greater collaboration with one another"18 , but it is said without appreciation of democracy: "The articulation of political authority at the local, national and international levels is one of the best ways of giving direction to the process of economic globalization. It is also the way to ensure that it does not actually undermine the foundations of democracy ${ }^{\text {“19 }}$.

Offhandedly, just Robert Nelson rightly wrote that economics must not be treated as religion because it would be a collapse of the civilization ${ }^{20}$. But economics (in a neoliberal version) began "religion"21, Nelson added. It is a result of "the secularization of the market"22. Nelson offers a theological exegesis of the contents of modern economic thought.

The economy should be supported by the religion and morality, the Pope would say ${ }^{23}$. Everybody is talking about ethics, business ethics, but what does it mean in practice?

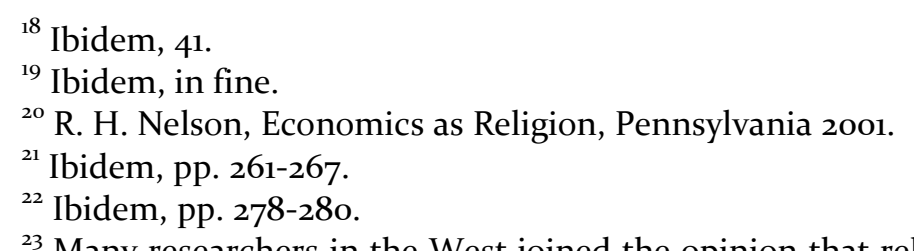

${ }^{23}$ Many researchers in the West joined the opinion that religion may effectively support the market. These are e.g. Amartya Sen, R. Nelson, but the beginning of this idea I have found in the philosophical-moral treaties of $18^{\text {th }}$ century classic of economy Adam Smith (see J. Evensky, op. cit.). See also very rich literature in the field in the West: Religion and Economics. New Perspectives, ed. by B. D. Chilton, J. Neusner, Binghamton 2000; R. H. Preston, Religion and the Ambiguities of Capitalism, Cleveland 1991; K. E. Boulding, Beyond Economics. Essays on Society, Religion and Ethics, Michigan 1968; Global Economics and Religion, ed. by J. Finn, New Brunswick, London 1983; Religion and Economic Ethics, ed. by J. F. Gower, Lanham, New York, London 1985; Religion and Economics: Normative Social Theory, ed. by J. M. Dean, A. M. C. Waterman, Boston, Dordrecht, London 1999; Economics and Religion: Are They Distinct?, ed. by G. Brennan, A. M. C. Waterman, Boston, Dordrecht, London 1994; A. Reich, Wirtschaftsethik. Grundlagen in theologischer Perspektive, Aachen 1984. Another thinkers, much more concerned with the left, say about economy based on the respect with human rights (e.g. Manuel Couret Branco) or on global justice (Zygmunt Bauman, Richard Miller). See: M. C. Branco, Economics Versus Human Rights, London, New York 2009, where he, fighting with, I would say, the wild face of contemporary capitalism in the developing countries, writes about "the hegemony of market ideology", "territorialization of democracy and deterritorialization of global economy" (pp. 109, 120); Z. Baumann, Does Ethics Have a Chance In a World of Consumers?, Cambridge, Massachusetts; London, UK 20o8, where he undermines "the logic of global responsibility" of Europe and its "role of a global pattersetter", especially in the Third World (pp. 256-257). Bauman is right when he mentions that "the world today seems to be conspiring against trust" (p. 63); it is a collapse of trust in society, and in economy, the market too. See also: R. Miller, Globalizing Justice. The Ethics of Poverty and Power, Oxford 2010. Miller's point of view seems to be anti-American. He criticizes "Empire" for a lack of special "duties" in the world or "imperatives of charity". Because being "Empire" implies duties. He calls for "global social democracy" with "global movement of social movements" and "global civic friendship". Sometimes it seems to be at least an Utopian vision of global society and sounds more naïve as the author thinks, surely. 
When we look at many great financial institutions like Enron, AIG, Citigroup, the fund investment like Madoff's, Fannie Mae, Freddie Mac etc., could not we ask where is a "normal", "ordinary" morality, kindness? Is the business ethics only an etiquette, a form, a decorum? For why should it be? For good feeling of the business people and the business world? Benedict rightly writes in this context: “»Striving to meet the deepest moral needs of the person also has important and beneficial repercussions at the level of economics. The economy needs ethics in order to function correctly - not any ethics whatsoever, but an ethics which is people-centred. Today we hear much talk of ethics in the world of economy, finance and business. Research centers and seminars in business ethics are on the rise; the system of ethical certification is spreading throughout the developed world as part of the movement of ideas associated with the responsibilities of business towards society. Banks are proposing "ethical" accounts and investment funds. "Ethical financing" is being developed, especially through micro-credit and, more generally, micro-finance. These processes are praiseworthy and deserve much support. Their positive effects are also being felt in the less developed areas of the world. It would be advisable, however, to develop a sound criterion of discernment, since the adjective "ethical" can be abused. When the word is used generically, it can lend itself to any number of interpretations, even to the point where it includes decisions and choices contrary to justice and authentic human welfare".

We abuse the term of business ethics or ethics in general, making an impression that everything can be ethical because of names used in titles of products, services, goods, codes, teaching programs or their contents, and in a promotion or an advertisement. It seems to be a hypocrisy or at least an etiquette of ethics (i.e. slogans of forms of moral values for public relations aims or selfish interests) in the written world but completely without any concrete meaning, sense and practical relevance or reference to concrete behavior in human life or corporate activity. I mean values are about the concrete behavior. It is not Plato's world of ideas which are objective and sitting near Athena in the heaven. We are on the earth and we can find both the values such as transparency, truth, fairness or honesty and the anti-values such as greed, lie, misinformation or envy in activity of concrete people in the market, business.

One would say that the norms of morality are too general and the market and their professional (often) participants such as bank, firms, analytics, managers, directors must have another concrete norms. On the one hand, that is true - the norms of morality, the 
values such as justice, truth, trust, kindness, fairness are general universal values, but on the other hand the value is an idea of good behavior which may be conceptualized and being developed in many concrete provisions: in the law of the state (the parliament acts, the government acts, the precedents), in the codes of good practices, in the principles of corporate governance, in the code of ethics, in the agreements. But the value, first of all, is behavior itself. It is very difficult to defense an opinion that somebody who committed a crime of fraud like Madoff is not theoretically and practically oriented in the moral values because these are "too" general... It would be a kind of real social or "economic" hypocrisy.

Man is a part of the economy and the market and human relations are something wider that commercial relations which are only a part or a kind of human relations. Benedict says that "Fidelity to man requires fidelity to the truth, which alone is the guarantee of freedom (cf. Jn 8:32) and of the possibility of integral human development" ${ }^{\text {.24 }}$ In my opinion, the transparency of commercial relations is a concrete result of this thinking - of thinking in this category. The problem of a lack of transparency was visible in the financial crisis and is still visible in unfair behaviors in business. So Benedict would like to remind everyone ("especially governments engaged in boosting the world's economic and social assets") that "the primary capital to be safeguarded and valued is man, the human person in his or her integrity", and "Man is the source, the focus and the aim of all economic and social life"25. It is especially addressed to the governments in order to correctly regulate and control the system but it concerns also relations in the market, the commercial relations, the ethics in business between professional participants of the markets and nonprofessionals, consumers etc.

Now we can consider what business ethics means.

\section{Business ethics. A term, history of studies and some chosen assumptions (Jennifer Jackson's proposal).}

According to Professor Jennifer Jackson from University of Leeds and her definition included in Encyclopedia of Business Ethics, business ethics is "the study of what is ethically permissible and of what is positively virtuous, in regard to business activity". Jackson adds that it is "an attempt not only to reach conclusions but to understand what lies behind

\footnotetext{
${ }^{24}$ Ibidem, 9 .

${ }^{25}$ Ibidem, 25.
} 
them. It is a branch of applied ethics. As such it draws on ethical theories and concepts and brings these to bear on problems and issues that arise in and for business" ${ }^{26}$.

It is not true that the business ethics has no a long tradition, Jackson directly mentions. Just a famous philosopher, lawyer and politician Cicero considered whether it was behavior morally wrong or unethical not to disclose to a prospective buyer of one's property that it had some defects, i. e. it was infested with wood worm ${ }^{27}$. So the history of considerations on ethics in business is not so short as sometimes it seems to be. Of course, since the early 1970 s the subject of business ethics has come to be treated as a specific area of academic study. Most main business schools in the U.S. have this subject in the curricula. We see increasing academic interest in the field. It is quite natural also in another countries. ${ }^{28}$ If business can be treated as a moral phenomenon and economic activity can be morally evaluated, then we should conclude that the concepts and theories of moral and political philosophy can be used in the analysis of business.

So why were we interested in the business ethics? There were not only "the philosophically intriguing questions that underline our puzzlement as to whether certain activities and policies in business are ethically defensible", Jackson says. So where were the main reasons of the business ethics development (treated as a part of scientific reflection)? It seems to be stemmed from the changes that are still occurring in the practice of business,

\footnotetext{
${ }^{26}$ J. Jackson, Business Ethics. Overview, [in:] Encyclopedia of Business Ethics, London 1991, p. 398. ${ }^{27}$ Ibidem.

${ }^{28}$ Ibidem. See more widely about business ethics, also in cultural and religious contexts: N. Hoerster, Ethik und Interesse, Stuttgart 2003; International Business Ethics. Challenges and Approaches, ed. by G. Enderle, Notre Dame-London 1999; A. Sen, Economics, Business Principles, and Moral Sentiments, [in:] International Business Ethics..., p. 15; H. Kueng, A Global Ethics in an Age of Globalization, [in:] International Business Ethics..., p. 109; T. Abeng, Business Ethics in Islamic Context: perspectives of Muslim Business Leader, [in:] International Business Ethics..., p. 237; M. Umezu, Ethics and the Japanese Miracle: Characteristics and Ethics of Japanese Business Practice, [in:] International Business Ethics..., p. 373; P. Koslowski, Ethik der Banken. Folgerungen aus der Finanzkrise, Muenchen 2009, p. 11; The Oxford Handbook of Business Ethics, ed. by G. G. Brenkert, T. L. Beauchamp, Oxford 2010; R. H. Frank, What Price The Moral High Ground? Ethical Dilemmas in Competitive Environments, Princeton, Oxford 2004, pp. 58-9o, where Robert H. Frank asked if socially responsible firms could survive in competitive environments; D. Vogel, The Market for Virtue. The Potential and Limits of Corporate Social Responsibility, Washington 2006, where David Vogel analyzed case studies of Nike, Ikea, Starbucks, Home Depot, British Petroleum, Shell, Citibank, PepsiCo, McDonald's, Chinquita, Timberland. See also: A. L. Gitlow, Corruption in Corporate America. Who is Responsible? Who Will Protect the Public Interest?, Lanham, Boulder, New York, Toronto, Oxford 2005; D. Vickers, Economics and Ethics. An Introduction to Theory, Institutions, and Policy, Westport, London 1997; Reputation. Studies in the Voluntary Elicitation of Good Conduct, ed. by D. B. Klein, Michigan 1997.
} 
in the business life. These changes begun in the 1970s and related to problems how business is conducted and how society perceives business. There are the following changes:

1. "the changing social expectations of business", it means that people, consumers, citizens expect that business will be responsible for the community, creating some social programs, one could say about "the responsibility of government";

2. "the impact of consumer boycotts on big business", it relates to efforts of firms to show and justify their ethical products, services to the public;

3. "the need for countries to agree on common standards of employment", that is to create a "single" market concerning conditions of labor;

4. the need for corporations to spell out common codes of practice for members of the corporation (what concerns higher clarity and understanding of aims inside corporations);

5. "the adverse impact multinationals", when a company operates around the world, also e.g. in fragile economy or become politically involved in the developing countries, or you meet an old problem of bribes or corruption in these countries, or you are going to abuse your economic position in politically and economically weak countries;

6. "the threat of legislation to curb what is perceived as irresponsible management and commercial practices, which is itself an incentive for firms to demonstrate their willingness and ability of self-regulation", that means that firms want to demonstrate what practices should be banned, punished because of their immorality, unethical foundations or essence ${ }^{29}$.

Ethics in business is not an etiquette in business. A great misunderstanding.

The changing social consciousness, the developing world of consumers, the marketing efforts of firms to be presented as ethically valuated organizations with ethically good products and services and all the aspects of economic activity (production, distribution etc.) - all these processes and reasons have some an influence on the business ethics. But we must conclude that from one statement that the considerations about ethics

\footnotetext{
${ }^{29}$ J. Jackson, op. cit., p. 399.
} 
in economic activity and business life are increasing (e.g. we have many studies in the field, special courses organized by the universities, experts, researchers for the management, special workers of corporations etc.) does not imply that the business life is more moral or morally better. It maybe that on the one hand, the moral feelings of professional participants of the corporation life, and on the other hand, social obligations of the managers and the management to be socially responsible, are "full of peace", are being “appeased". Let conscience leave in a peace - that maybe the most fundamental principle of interest of big business in the ethics in business understood as a scientific, philosophical and ethical science. "We know what it means, we participate in the studies in the business ethics, we also participate in many conferences and programs in business ethics, so do not care about our business and ethics, do not worry" - the answer given by the big business may sound.

In my opinion, it is a danger for business that the ethics in business, the business ethics is treated rather as a form, decorum, etiquette (the etiquette, we must add, that includes very strict and concrete rules how to welcome a partner, how to behave in an official situations, during the dinner etc., how to give our counterpart a gift or when not to do it, e.g. in China) than moral norms - the moral norms which concerns a vision of evil and good; to saying shortly and to sum up, the business ethics concerns a problem of what is morally good or morally wrong behavior in the business. It always relates to the individuals: it first concerns the professionals (I guess that collective liability is also individual for one person) but also consumers. It is not an etiquette; it is a mistake to mention that the etiquette in business is the business ethics. It seems to be a great misunderstanding. The etiquette should be only an external form of "internal" moral foundations of behavior and really deeply axiological norms which are moral norms conceptualized and expressed in concrete human acts in business. To treat the etiquette as the ethics it is a kind of awful and deliberate cynics and hypocrisy in the present-day business. I do not mean a lack of knowledge or intellectual horizons in discovering relations between business and ethics. It is a "clever way" proposed by a "code of everyday business experience", paraphrasing Leon Petrażycki. Follow it, if you want to be a gentle (and nice) businessman, it says to us.

I agree with Julie A. Nelson, when she writes that we are real people with the real emotions and the ethics, and in life of corporation there are many acts and activities which 
can be treated as moral or immoral acts. That is the "ethical decision making" problem ${ }^{30}$. Of course, we could consider if the market is generally moral ${ }^{31}$, but it seems to be certain that a virtue is a moral capital in a corporation, and managers who have not a virtue have not the moral capital (e.g. in Enron) $)^{32}$. So business ethics cannot be only "an ideal" but must be also "reality"33.

\section{John C. Bogle's ten statements about practice of ethics and about current business ethics. Real principles, not a dead letter.}

In 2009 John C. Bogle, who worked all the life in business (exactly 57-year in corporations), wrote a book about business ethics, from practical, not theoretical and philosophical, point of view. The title interestingly sounds: "Enough". The subtitle is "True Measures of Money, Business, and Life"34. He sees the business ethics problem more widely as practical validation of ten principles in markets, business and social life. Methodologically, the principles are de facto results of descriptions of some phenomena appeared in the markets, business and social life. The first, there is "Too Much Cost, Not Enough Value". There is too less moral value in business. Business is only about costs, money but it is not the only one aim of business. The environment where business lives is wider. If you do not understand the rights of the others (workers, their families, clients, consumers, local communities, a state), you do not understand anything. The second, "Too Much Speculation, Not Enough Investment". Hardly nobody wants to invest in a long-term period (as Keynes wanted to see it) but everybody wants to have the fast profit, gain, outturn. The third, "Too Much Complexity, Not Enough Simplicity". There are so many financial instruments which seem to be sophisticated and not understood in the field of risk. We can generally remember that financial sector should function in the public interest. These principles concern the field of "Money". The next principles relate to the "Business" field. So the fourth, there is "Too Much Counting, Not Enough Trust". We have such many

\footnotetext{
${ }^{30}$ J. A. Nelson, Economic for Humans, Chicago, London 2006, pp. 108, 127.

${ }^{31}$ See more: R. M. Blank, W. McGurn, Is the Market Moral? A Dialogue on Religion, Economics and Justice, Washington 2004.

${ }^{2}$ A. J. G. Sison, The Moral Capital of Leaders. Why Virtue Matters, Cheltenham, UK; Northampton, USA 2003, pp. 24-35;

${ }^{33}$ K. M. Leisinger, K. M. Schmitt, Corporate Ethics in a Time of Globalization, Sri Lanka, Ratmalana 2003, pp. 2-40.

${ }^{34}$ J.C. Bogle, Enough. True Measures of Money, Business, and Life, New Jersey 2009. vol.08, $n^{\circ}$. 01, Rio de Janeiro, 2015. pp. 458-488 475
} 
experts and so much mathematics in the financial sector but business organizations must learn that "not everything that can be counted counts". The fifth, "Too Much Business Conduct, Not Enough Professional Conduct". Business conduct (e.g. etiquette) should be in relation with ethical professionalism. The sixth, "Too Much Salesmanship, Not Enough Stewardship". We can ask: where is a vision that industry is "of the shareholder, by the shareholder and for the shareholder"? Where is a fiduciary duty, trusteeship and integrity in serving clients? There is undoubtedly a necessity of the proven principles of long-term investing. The seventh, “Too Much Management, Not Enough Leadership”. As Bogle writes that it had been observed that most of the U.S. larger corporations were "overmanaged but underled". The last principles relate to the field of "Life" treated as all the social order. So the eighth, "Too Much Focus on Things, Not Enough Focus on Commitment". Where is trust and confidence? We are good in the details but not in the commitment. The ninth, “To Many Twenty-First-Century Values, Not Enough Eighteenth-Century Values”. The collapse of the moral and traditional values is visible in a lack of commitment to family and community, in the lack of boldness (being brave but not impudent) and the providence commitment. The tenth, Bogle says to us: "Too Much 'Success', Not Enough Character". Which measures should we choose to be wealthy? Fame and Power? There is too less character, courage, honor, contemplation in doing the business.

The business ethics is not a theory or only "words, words, words" (as Shakespeare would say) but the first and the most fundamental principle is that the ethics should be applied to practice in different way (by concrete behavior in business relations, not only by entering into force a code of good practice etc.). I think that business ethics should be based on honesty and transparency in business or economic activity and these moral values should be moral criteria of evaluation of any human acts in business.

\section{THE PRINCIPLES OF BUSINESS ETHICS.}

Thus are there any real ethical principles in business? Yes, they are there, being universal. They are the values. Of course, I understand that in some regions or cultures it may be more sophisticated and based more on the local tradition but nobody normal should accept a bribe as a form of honesty in business. It would be a degeneration in the system, supporting inequalities and destroying, even formal but equal, opportunities. Thus we can prompt that the principles are as follows: 
1. Truth, and human dignity, and human freedom;

2. Honesty;

3. Transparency;

4. Justice;

5. Kindness;

6. Love;

7. Charity;

8. Trust and keeping promises;

9. Integrity of actions;

10. Responsibility;

11. Predictability;

12. Understanding social needs of local community (corporate social responsibility);

13. Supervision and controlling;

14. Dialogue;

15. Respect to the law;

16. Respect to the internal official documents (strategy and public offers);

17. Loyalty and confidence ${ }^{35}$;

18. Clarity (of rules and behavior, and expectations).

What I want to underline now is, first of all, that every value may be widely developed, using many examples from practice of business. The second, a classification of is not about the abstract values, the values are in our business behavior or in behavior in a company or in the market. We cannot forget that values are in concrete behavior of the concrete people, even if the decision is made by the corporate body such as the board or the management as whole. It does not matter - the decisions must be evaluated in this way that we must evaluate the concrete behavior of the concrete man. Ethics is about individual action of one man, of course especially in relation to the others, the men, but also to the another states of things (such as environment, the law etc.).

\footnotetext{
${ }^{35}$ Even if the classification sounds arbitrary I can remind per analogiam John Locke's thesis about the limits of government: in some circumstances absolute power is necessary but is not arbitrary and still has some limits concerning the public good. All theory is absolute but only part of it is arbitrary. And one more to mention Locke's considerations about the state of nature I can add that a reason is a limit of all activity (he says sometimes: "reason", "the common law of nature", "the right rule of reason" and so on, look at footnote 38 ).
} 
What else to add about moral evaluation or moral feelings? Following David Hume's ideas $^{36}$ I may add that we have some moral intuitions based on a sympathy and human kindness which are able to prompt us what is morally wrong and what the real value means. We, in our hearts, have also feelings of disgust addressed to behaviors which are dishonest such as a fraud. It is a real harm for others than he who has committed a crime. The values, the principles are only general on a paper, they are very practical in behavior. We respect to them, or not to respect to them, that is clear.

\section{Philosophical background of the principles (values) of ethics in business, and one case study.}

Now it is time for a little deeper philosophical background of the values in business ethics. I choose the philosophers such as Kant, Smith, Locke, Hume to make this background. Let us start with Kant to talk about moral obligations. Thus Immanuel Kant's “The Categorical Imperative of Reason" orders to treat another man always as an aim, never as a measure to the aim. It concerns human dignity. Kant teaches us also that there are some Moral Laws, and a limit of my freedom is the freedom of the another man ${ }^{37}$. I must not abuse my power and freedom. I must not treat a man only as a measure.

Adam Smith in his "Theory of Moral Sentiments" $3^{8}$ is not a wild capitalist (or libertarian): he really supports the idea of human dignity, "certain virtues", and duties to the others, i.e. social duties to development of the community because of a fact that my prosperity implies prosperity of the others. That is about (respected by divine laws) love of individuals for the people, it is not, of course, about the government help in it.

\footnotetext{
${ }^{36}$ See more D. Hume, Enquiries Concerning the Human Understanding and Concerning the Principles of Moral, edition used: Enquiries Concerning the Human Understanding and Concerning the Principles of Morals by David Hume, ed. L. A. Selby-Bigge, M.A. 2nd ed., Oxford: Clarendon Press, 1902, available at http://oll.libertyfund.org (27.03.2013).

${ }^{37}$ See I. Kant, The Philosophy of Law: An Exposition of the Fundamental Principles of Jurisprudence as the Science of Right, trans. W. Hastie, Edinburgh: Clark, 1887, available at http://oll.libertyfund.org (27.03.2013), especially pp. 28-34.

${ }^{38}$ See A. Smith, The Theory of Moral Sentiments, ed. D.D. Raphael and A.L. Macfie, vol. I of the Glasgow Edition of the Works and Correspondence of Adam Smith, Indianapolis: Liberty Fund, 1982, available at http://oll.libertyfund.org (27.03.2013), especially pp. 6o-64. Smith starts his considerations about sympathy as follows: "How selfish soever man may be supposed, there are evidently some principles in his nature, which interest him in the fortune of others, and render their happiness necessary to him, though he derives nothing from it except the pleasure of seeing it. Of this kind is pity or compassion, the emotion which we feel for the misery of others, when we either see it, or are made to conceive it in a very lively manner" (p.6o).
} 
John Locke ${ }^{39}$, who so interestingly wrote about the state of nature, mentioned that the things in the world, all property, given by God, is not to destroy or spoil but to develop all the mankind. The world given by God is enough rich to enjoy for everybody. The most fundamental law of nature is to preserve the mankind (obviously, a property is important but it is a wider concept of property including life, liberties and estates). The state is to protect peace, safety and the public good.

The mentioned above David Hume's idea of natural law is based on a value of sympathy and kindness, and all human relations should be based on sympathy, according to human nature ${ }^{40}$. But the same value of sympathy (human feelings like "pity", "compassion") can be found in Smith's theory ${ }^{41}$.

This philosophical background, found in both Kant, Locke and Hume, Smith, used to support my classification of the values is not ambiguous: business which is based on greed, envy, jealousy, maximization of profits, instrumentalisation of the other people (people do not treat human dignity of the others seriously), false relations (a lie or hypocrisy is a truth) or quasi-slavery relations (a worker is a slave; a consumer, too), misinformation or even fraud, is contrary to an ideal which is required, even partially, to be a better reality.

Taking Ronald Dworkin's theory ${ }^{42}$ seriously, we can highlight that, of course, the principles, i.e. the values, may be in conflict. They act on a principle "less or more". They should be interpreted complementary in a comprehensive fair interpretation, without omitting important principles in a case. E.g. look at the points: a, c, h and q. Let us imagine a situation. A seller wants to sell a company. A buyer wants to buy it. A price is known for

\footnotetext{
39 See J. Locke, Two Treatises of Government, ed. Thomas Hollis, London: A. Millar et al., 1764, available at http://oll.libertyfund.org (27.03.2013), especially pp. 97-117, 148-150.

${ }^{40}$ D. Hume, op. cit. See what he writes about benevolence: "It may be esteemed, perhaps, a superfluous task to prove, that the benevolent or softer affections are estimable; and wherever they appear, engage the approbation and goodwill of mankind. The epithets sociable, good-natured, humane, merciful, grateful, friendly, generous, beneficient, or their equivalents, are known in all languages, and universally express the highest merit, which human nature is capable of attaining. Where these amiable qualities are attended with birth and power and eminent abilities, and display themselves in the good government or useful instruction of mankind, they seem even to raise the possessors of them above the rank of human nature, and make them approach in some measure to the divine. Exalted capacity, undaunted courage, prosperous success; these may only expose a hero or politician to the envy and ill-will of the public: but as soon as the praises are added of humane and beneficent; when instances are displayed of lenity, tenderness or friendship; envy itself is silent, or joins the general voice of approbation and applause" (p. 109).

${ }^{41}$ A. Smith, op. cit., p. 60.

${ }^{42}$ See R. Dworkin, A Matter of Principle, Cambridge 1985.
} 
them. But the buyer does not want to inform the public because he has some fears that it would be a subject of social envy or outrage. So they agreed that the price is confident. On one hand, truth orders to say about the prices. Transparency would prompt that the public should know the price. It would be a clear business. On the other hand, loyalty in business is based on keeping some information far from the public or another businessmen. Trust and keeping promises prompt that we should not say anything about the price to the others. What to choose? That is a real moral (ethical) dilemma. I think that in general loyalty and trust are a basis of business but in some circumstances, taking the public interests and only very important public reasons seriously, truth and transparency should "break" the another principles such as loyalty and confidence to make the whole business world transparent. However, it is the hard weighing values process! What is a real basis of real business should not be, even if it is a moral value as loyalty or confidence, the only one basis of the business ethics. It belongs to how socially important things are behind a business contract.

\section{What the research should be carried out in the future.}

However, analyzing functioning and activities of global financial institutions during the economic crisis and their standards, we can imply on the genesis, essence and effects of the crisis. And to consider - what to do in the future? Or maybe Jared Diamond ${ }^{43}$ is right: we are unconsciously going to the collapse of the society on own demand?! For me, the financial crisis is rather axiological crisis than only economic crisis. It is a crisis of legal regulations and a crisis of ethics in business. A lack of axiology in economy (a collapse of traditional ethics, a greed and dishonesty in economy) and a lack of legal regulations (financial de-regulation) were the reason of the crisis. Overregulation would be also wrong. It would create less flexible world of rules, bureaucracy and the "big brother" world. "Golden rule" that is based on restraint reason and was imagined by Aristotle is a correct way to make use of it.

Remembering the former chief of the Federal Reserve's famous words that he found a gap in his reasoning and theory but he did not know what it was, we can add that we know what is was. We must build the models of relations between law, morality, economy which describe these phenomena such as COLLAPSE OF ETHICS IN BUSINESS OR

${ }^{43}$ See J. Diamond, Collapse: How Societies Choose to Fail or Succeed, New York 2005. vol.08, $n^{\circ}$. 01, Rio de Janeiro, 2015. pp. 458-488 
DEGENERATION OF ethics in business OR DEPRECIATION OF LAW IN PRACTICE OF BUSINESS in a critical moment before or during of the financial crisis and could answer the question how to fight with such the crisis in the future by strengthening the role of ethics in business and the law in financial markets. In general in order to build a good model (or models) of the relations it would be necessary to carry out the very wide, systematic, comprehensive, multidisciplinary and comparative and both theoretical (conceptual and normative) and practical (based on case studies) research in the field:

1. Theoretical relations between law, morality and economy;

2. Axiological foundations of economy, the values in the economy market;

3. Law as a measure of regulation of human acts, and its efficiency;

4. Morality as a system of norms, and professional ethics;

5. Greed as an anti-value and a result of consumerism and hedonism;

6. Business ethics, a correct meaning, and its rules and principles;

7. Corporate governance, universal standards and cultural differences;

8. Codes of good practices;

9. Ethical codes in corporations and companies, and unofficial unethical rules;

10. Legal regulations during and after the financial crisis, state and corporate supervision or control;

11. The real axiology in business (not written in the codes but used in practice, the case studies, false morality full of hypocrisy, morality based on consumerism, the real behavior, the real morality in practice both in professional sphere and within consumers) with a slogan "Forget about the institutional axiology" (ethics, morality, declared or normative spheres such codes, strategies and so on). That is the most important part of the study!

12. Models of relations between law, ethics, economy.

\section{FINAL WORDS. CONCLUSIONS}

Ethics, business ethics, corporate governance and corporate law are strictly related. A lack or, to be more precise, a lack of a high level of implementation or understanding of corporate governance and ethics in business before and during the global financial crisis begun in 2007 are too much visible in relations in the market. We are observing the effects of such the state of things. There is no economy and economic activities without much 
more deeper foundations based on moral universal values such as honesty or transparency. The global financial crisis is rather an axiological crisis than strictly economic because the foundations and real reasons of the financial crisis have strictly moral character. Greed, profit, fraud and misinformation as a norm, the new morality of homo economicus have created the new world of consumers and the structurally and institutionally hermetic world of the markets and the corporations, and the actual state of things in economy what we call "the global financial crisis". Honesty, transparency, integrity of actions seem to be too "morally" odd and too less pragmatic values to be realized in practice now. It is a sad but more realistic view of the corporations and economy. I suppose that it is the real view, and although the necessity of legal and corporate changes is completely understandable and even certain, the possibility of the realization of the standards seems to be so ambiguous. It is not only the problem of human nature or hermetic corporations and their interests or sophisticated financial instruments but also a will of politicians and a consciousness of public opinion. Does anybody have conscience pangs? It sounds, one more, rhetoric.

Now I want to strictly and strongly highlight expressis verbis that we may not agree with the former Pope Benedict's religious teaching or political and social or moral ideas in many areas but his axiological and ethical point of view of the current financial crisis seems to be interesting and corresponds with many opinions of the left, social democrats and even neo-Marxists economists, philosophers and sociologists such as Zygmunt Bauman ${ }^{44}$, Michel Husson, Sussan George and Slavoy Zizek (I am also reading them with interest but most of them I treat as naïve speakers near the next unknown Utopia) in the field of factual reasons of the crisis which should be especially treated as a moral crisis. In my opinion it seems to be a great paradox, implying that completely different thinkers treat the financial crisis not only as an economic crisis but as having much more deeply axiological and moral impacts, reasons, sources such as greed of companies and consumers, corruption in companies, bad governance in companies, a lack of ethics in business. People from the left to conservative religious ideology and the old institutional religion see the same (the reasons of the crisis) in the similar eyes - it is hilarious for me! So what does it mean for policy recommendations? Thus nothing.

History of slavery is like a circle: free people became stupid consumers, that is the lost freedom; free people working in corporations became its cynical or ordinary slaves, the

\footnotetext{
${ }^{44}$ Compare footnote 22.
} 
honest became the dishonest, that is the real drama of our times and values; free people became dishonest businessmen and businesswomen, vulgar liars, without heart, mercy and reason. That is the second, more awful, side of business without which we cannot live now.

One can say: do not worry about the mankind, they did not change too much from Machiavelli times... Maybe it is true but the present-day world has real problems and even the history of Roman law and Roman jurists like Cicero mentioned in this paper may tell us that an essence of contract is a honesty and keeping promises. And truth about wood worm what concerns consumers. Cicero would say also about slavery: we are naturally free but social order creates inequalities (look at Grotius or Hobbes, too, and even have a look at Locke, they would agree). A famous Roman lawyer Ulpian said: Honestum vivere! It sounds ethical, not legal. IN this current social and economic system it is too much slavery. Institutional corporate serfdom joined biological consumerism, false ethics as etiquette, wanting money, even virtual, and people's greed. Is this a sense of life?! The states are so weak that every regulation follows by next de-regulation that then begins regulation etc. This crazy circle must be broken in psychology of mass and individuals, not in normative sphere.

Consumerism reigns. How long? What is its relation to collapse of ethics? It sounds serious. It is said that I consider whether the collapse of the real business ethics and the hypocrisy of moral values in the corporations (so called corporate governance) are visible facts. They are. It is also said about my research that ethics, morality, new style of life based on idea "less consumerism, less greed, less desires" may change the "axiologically and morally ill" social and legal orders. Yes. I still believe in moral education and free and responsible people who are not so silly to participate in an work of greed, evil and moral decay. Enough!, let us repeat, following Bogle. New order is necessary: not economic, not legal, not ethical, too, but new values in our hearts and minds which will become the real behaviors in practice of many people in the world. It is about changing the real axiology in business and consumers' life.

Forget about the institutional axiology written in the state law or codes of good practices, codes of corporate governance or any official documents of companies. Look at the case studies (Enron, Lehman Brothers, Madoff etc.) and the real axiology. Let us flash on the values in our behavior. Then we will be on a good way to go back to the good values. 
It is not good to be an slave, being, on one hand a worker (an ordinary worker or a member of management) in a corporation, and on the other hand being a silly consumer. Well, one can remind Epictetus one more who unchanged teaches us that we are really free when we have no too much desires (not caring about both legal and moral issues too much as well). Just we are going back to a problem of our greed. It is a circle: how the contemporary slavery in the market or in the business is more sophisticated and distinguished from that used in the ancient times, being in an essence the same.

We are slaves of the ill social sub-systems: economic system, legal system, consumerism ideology, advertisement system and media system where we live in. And the solution is not in these systems, it is inside us, in our hearts, minds. Follow a reason, as John Locke would say. The law is based on the reason. It cannot be another, Immanuel Kant would add. Moral sentiments are a part of our human nature, David Hume and Adam Smith teach us. Going back to the classics and follow our reason to understand that our world is very sad in this egoistic, hedonistic, and materialistic restoration of blasphemy nowadays, and we are not really free but we want to be free, maybe not "absolute lords", as Locke wrote about a state of nature, but really free in this sense that we have a choice not to participate in the ill system or change it totally, even by a force or violence. First of all, a consciousness should be changed; the second, our mind should then influence on our behavior, and the real axiology; the third, it will be time for changing the institutions. It is not a socialist revolution (however, why not to say that it sounds like a conservative religious revolution? I am sorry, we live in time of blessings of political correctness), I am very far from socialism, it is only a reminder that we have human dignity because we are people and nobody is apt to justify unjustified orders, the orders based on crazy consumerism and soft psychological power over biological instincts, which are full of hypocrisy (e.g. bail-out, public support for private companies; treating people as wild consumers, and consumption as a way of life). When the system is rotten it is time for new order, new axiology and spoiling this slavery. It is still a democracy. But it is the Lockean dissolution not only of the government in political sense, it is the dissolution of all the governments (constitution and politics, law, business, media, culture, morality, education) in the state. That is right that after the revolution of minds we need the new refurbishment of the institutions, the institutional axiology, too. Now we have the slavery and it is morally wrong, human dignity is destroyed, and cynical business is not responsible for the people's 
public good; the people who are a sovereign, not only consumers. The problem is that we do not know where we are going to, and we are still like slaves in the ancient times, we have our masters (in business and politics and media, and consumerism system) but we have no freedom because we are still manipulated by the rotten system. As was said, it is possible to change ethics in business. We should start with moral education to make ordinary people, the citizens, who create the commonwealth, really more responsible, competent and free in choices.

Then we will change the world, not, not, not like Marx wanted (I am in general the worst of his opponents, especially in relation to his proposals, but not to his diagnosis, I mean the young existential Marx), but as the universal objective, maybe a little conservative, maybe a little liberal, maybe a little communitarian, values want!

\section{ÉTICA, ÉTICA NOS NEGÓCIOS E A CRISE FINANCEIRA. SOBRE AXIOLOGIA E NEGÓCIOS: A HISTÓRIA DA ESCRAVIDÃO COMO CICLO.}

\section{Resumo}

No presente artigo há a tentativa de familiarizar o leitor com problemas de ética e ética nos negócios, em um contexto de crise financeira. $\mathrm{O}$ artigo procura delinear o papel da ética como fator atuante no mundo dos negócios. Uma abordagem ética é extremamente importante na economia e na atividade empresarial. Não há economia ou atividade econômica louvável se não houver axiologia, um fim social. Não há economia e atividade econômica sem fundamentos muito mais profundos, com base em valores universais morais como honestidade ou transparência ou dignidade. Devemos voltar ao ensino papal e ao estudo da filosofia moral clássica. Eu acredito que nós podemos criar a axiologia real, incluindo esses valores. A crise financeira mundial é também uma crise axiológica e não estritamente econômica, porque os fundamentos e as razões reais da crise financeira tem caráter estritamente moral. A ganância, o lucro, a fraude, a desinformação e a nova moralidade do homo economicus criaram o novo mundo dos consumidores e do mundo estruturalmente e institucionalmente hermético dos mercados e das corporações. É uma visão triste, mas mais realista sobre as corporações e a economia. A história da escravidão é como um ciclo: o homem livre se tornou um consumidor estúpido; o trabalhador livre se tornou um escravo das corporações; o honesto se tornou desonesto; pessoas livres se tornaram desonestos homens e mulheres de negócios, sem coração, misericórdia ou razão. O sistema em que vivemos está podre (política, direito, economia, mídia, ideologia consumista), exigindo mudanças. Deviamos começar melhorando a educação moral, a fim 
de que o homem comum, o cidadão, aquele que cria a comunidade, torne-se de fato mais

responsável, competente e livre em suas escolhas.

Palavras-chave: moral, ética, ética nos negócios, axiologia, valores, crise financeira, escravidão, liberdade, filosofia moral, lei, ordem social, o consumismo, o sistema podre.

\section{BIBLIOGRAPHY}

ABENG T., Business Ethics in Islamic Context: perspectives of Muslim Business Leader, [in:] International Business Ethics. Challenges and Approaches, ed. by G. Enderle, Notre Dame-London 1999.

BAUMAN Z., Does. Ethics Have a Chance In a World of Consumers?, Cambridge, Massachusetts; London, UK 2008.

BENEDICT XVI, Caritas in veritate, Vatican 2009.

BLANK R. M., McGurn W., Is the Market Moral? A Dialogue on Religion, Economics and Justice, Washington 2004.

BOGLE J. C., Enough. True Measures of Money, Business, and Life, New Jersey 2009.

BOULDING K. E., Beyond Economics. Essays on Society, Religion and Ethics, Michigan 1968.

BRANCO M. C., Economics Versus Human Rights, London, New York 2009.

BRENKERT G. G., Beauchamp T. L. (eds.), The Oxford Handbook of Business Ethics, Oxford 2010.

BRENNAN G., Waterman A. M. C. (eds.), Economics and Religion: Are They Distinct?, Boston, Dordrecht, London 1994.

CAMERON S., The Economics of Sin. Rational Choice or No Choice at All?, Cheltenham, UK; Northampton, USA 2002.

CHILTON B. D., Neusner J. (eds.), Religion and Economics. New Perspectives, Binghamton 2000.

DEAN J. M., Waterman A. M. C. (eds.), Religion and Economics: Normative Social Theory, Boston, Dordrecht, London 1999.

DIAMOND J., Collapse: How Societies Choose to Fail or Succeed, New York 2005.

DWORKIN R., A. Matter of Principle, Cambridge 1985. 
ENDERLE G. (ed.), International Business Ethics. Challenges and Approaches, Notre Dame-London 1999.

EVENSKY J., Adam Smith's Moral Philosophy. A Historical and Contemporary Perspective on Markets, Law, Ethics, and Culture, Cambridge 2005.

FINN J. (ed.), Global Economics and Religion, New Brunswick, London 1983.

FRANK R. H., What Price The Moral High Ground? Ethical Dilemmas in Competitive Environments, Princeton, Oxford 2004.

GITLOW A. L., Corruption in Corporate America. Who is Responsible? Who Will Protect the Public Interest?, Lanham, Boulder, New York, Toronto, Oxford 2005.

GOWER J. F. (ed.), Religion and Economic Ethics, Lanham, New York, London 1985.

GREIDER W., The Soul of Capitalism, New York, London, Toronto, Sydney, Singapore 2003.

HOERSTER N., Ethik und Interesse, Stuttgart 2003.

HUME D, Enquiries Concerning the Human Understanding and Concerning the Principles of Moral, edition used:

Enquiries Concerning the Human Understanding and Concerning the Principles of Morals by David Hume, ed. L. A.

Selby-Bigge, M.A. 2nd ed., Oxford: Clarendon Press, 1902, available at http://oll.libertyfund.org (27.03.2013).

JACKSON J., Business Ethics. Overview, [in:] Encyclopedia of Business Ethics, London 1991.

KANT I., The Philosophy of Law: An Exposition of the Fundamental Principles of Jurisprudence as the Science of Right, trans. W. Hastie, Edinburgh: Clark, 1887, available at http://oll.libertyfund.org (27.03.2013).

KLEIN D. B. (ed.), Reputation. Studies in the Voluntary Elicitation of Good Conduct, Michigan 1997.

KOSLOWSKI P., Ethik der Banken. Folgerungen aus der Finanzkrise, Muenchen 2009.

KUENG H., A Global Ethics in an Age of Globalization, International Business Ethics. Challenges and Approaches, ed. by G. Enderle, Notre Dame-London 1999.

LEISINGER K. M., Schmitt K. M., Corporate Ethics in a Time of Globalization, Sri Lanka, Ratmalana 2003.

LOCKE J., Two Treatises of Government, ed. Thomas Hollis, London: A. Millar et al., 1764, available at http://oll.libertyfund.org (27.03.2013). 
MILLER R., Globalizing Justice. The Ethics of Poverty and Power, Oxford 2010.

NELSON J. A., Economic for Humans, Chicago, London 2006.

NELSON R. H., Economics as Religion, Pennsylvania 2001.

PRESTON R. H., Religion and the Ambiguities of Capitalism, Cleveland 1991.

REICH A., Wirtschaftsethik. Grundlagen in theologischer Perspektive, Aachen 1984.

RUSSELL B., The Impact of knowledge on the society, London, Sydney, Wellington 1952.

SEN A., Economics, Business Principles, and Moral Sentiments, [in:] International Business Ethics. Challenges and Approaches, ed. by G. Enderle, Notre Dame-London 1999.

SISON A. J. G., The Moral Capital of Leaders. Why Virtue Matters, Cheltenham, UK; Northampton, USA 2003.

SMITH A., The Theory of Moral Sentiments, ed. D. D. Raphael and A. L. Macfie, vol. I of the Glasgow Edition of the Works and Correspondence of Adam Smith, Indianapolis: Liberty Fund, 1982, available at http://oll.libertyfund.org (27.03.2013).

SOEDERBERG S., Corporate Power and Ownership in Contemporary Capitalism. The politics of resistance and domination, London-New York 2010.

UMEZU M., Ethics and the Japanese Miracle: Characteristics and Ethics of Japanese Business Practice, [in:] International Business Ethics. Challenges and Approaches, ed. by G. Enderle, Notre Dame-London 1999.

VICKERS D., Economics and Ethics. An Introduction to Theory, Institutions, and Policy, Westport, London 1997.

Vogel D., The Market for Virtue. The Potential and Limits of Corporate Social Responsibility, Washington 2006.

Trabalho enviado em o8 de outubro de 2014.

Aceito em 22 de janeiro de 2015. 